\title{
COMPARISON BETWEEN ALUMINUM OXIDE SURFACE PASSIVATION FILMS DEPOSITED WITH THERMAL ALD, PLASMA ALD AND PECVD
}

\author{
G. Dingemans ${ }^{1}$, P. Engelhart ${ }^{2}$, R. Seguin ${ }^{2}$, M. M. Mandoc ${ }^{1}$, M. C. M. van de Sanden ${ }^{1}$ and W. M. M. Kessels ${ }^{1}$ \\ ${ }^{1}$ Department of Applied Physics, Eindhoven University of Technology, 5600 MB Eindhoven \\ ${ }^{2} \mathrm{Q}-\mathrm{CELLS} \mathrm{SE}$, Sonnenallee 17-21, 06766 Bitterfeld-Wolfen, Germany
}

\begin{abstract}
Surface passivation schemes based on $\mathrm{Al}_{2} \mathrm{O}_{3}$ have enabled increased efficiencies for silicon solar cells. The key distinguishing factor of $\mathrm{Al}_{2} \mathrm{O}_{3}$ is the high fixed negative charge density $\left(Q_{f}=10^{12}-10^{13} \mathrm{~cm}^{-2}\right)$, which is especially beneficial for $p$ - and $p+$ type $c-S i$, as it leads to a high level of field-effect passivation. Here we discuss the properties of $\mathrm{Al}_{2} \mathrm{O}_{3}$ surface passivation films synthesized with plasma atomic layer deposition (ALD), thermal ALD (using $\mathrm{H}_{2} \mathrm{O}$ as oxidant) and PECVD. We will show that with all three methods a high level of surface passivation can be obtained for $\mathrm{Al}_{2} \mathrm{O}_{3}$ deposited at substrate temperatures in the range of $150-250^{\circ} \mathrm{C}$. Furthermore, the role of chemical and field-effect passivation will be briefly addressed. It is concluded that the passivation performance of $\mathrm{Al}_{2} \mathrm{O}_{3}$ is relatively insensitive to variations in structural properties. $\mathrm{Al}_{2} \mathrm{O}_{3}$ is therefore a very robust solution for silicon surface passivation.
\end{abstract}

\section{INTRODUCTION}

In the past few years, $\mathrm{Al}_{2} \mathrm{O}_{3}$ films have demonstrated their potential as surface passivation scheme for silicon photovoltaics by enabling ultralow surface recombination velocities [1-5] and enhanced solar cell efficiencies [6,7]. The key differentiator of $\mathrm{Al}_{2} \mathrm{O}_{3}$ in comparison to other passivation schemes is its high fixed negative charge density $\left(10^{12}-10^{13} \mathrm{~cm}^{-2}\right)$ located at the $\mathrm{Al}_{2} \mathrm{O}_{3} / \mathrm{Si}$ interface which produces effective field-effect passivation by shielding electrons from the interface. This makes $\mathrm{Al}_{2} \mathrm{O}_{3}$ especially suited for the passivation of $p$-type silicon and $p+$ emitters, while $\mathrm{Al}_{2} \mathrm{O}_{3}$ is expected to be less suitable for $n$-type (due to parasitic shunting) and $n+$ type silicon (yet this still remains to be proven). The thermal stability of $\mathrm{Al}_{2} \mathrm{O}_{3}$ during firing and the low temperature deposition of the films, are compatible with industrial solar cell processes [8]. $\mathrm{Al}_{2} \mathrm{O}_{3}$ is transparent (bandgap $\sim 9 \mathrm{eV}$ ) and stable under UV illumination $[9,10]$, but the refractive index of 1.64 makes it less suitable for single layer antireflection coating on the front side as compared to $a$ $\mathrm{SiN}_{\mathrm{x}}$. As a back reflector, however, $\mathrm{Al}_{2} \mathrm{O}_{3}$ is superior. Also the fact that very thin $\mathrm{Al}_{2} \mathrm{O}_{3}$ films (down to $5 \mathrm{~nm}$ ) can be used [5], is another benefit of $\mathrm{Al}_{2} \mathrm{O}_{3}$ and enables flexibility in the design of surface passivation schemes and stacks. As a consequence of these (unique) properties, $\mathrm{Al}_{2} \mathrm{O}_{3}$ is now considered as an important candidate for surface passivation in industrial solar cells, either for front and/or rear side passivation. A remaining challenge in this respect, is the development of deposition tools for $\mathrm{Al}_{2} \mathrm{O}_{3}$ films compatible with the requirements, especially in terms of throughput, of the solar cell industry.

To date, $\mathrm{Al}_{2} \mathrm{O}_{3}$ surface passivation films have been mainly synthesized with atomic layer deposition (ALD). The ALD growth process is based on self-limiting surface reactions, and therefore allows for film thickness control on the sub-monolayer level as well as excellent uniformity and conformality. A thermal and plasma ALD process for $\mathrm{Al}_{2} \mathrm{O}_{3}$ using $\mathrm{H}_{2} \mathrm{O}$ and an $\mathrm{O}_{2}$ plasma as oxidants, respectively, have been successfully tested for $\mathrm{Si}$ surface passivation. The traditionally low deposition rates of ALD, have been the incentive for testing of alternative deposition methods. It has for instance been shown that other techniques, such as sputtering and plasma enhanced chemical vapour deposition (PECVD) [11-14], can also be used to deposit $\mathrm{Al}_{2} \mathrm{O}_{3}$ for surface passivation. These methods generally allow for higher deposition rates and are well established in solar cell manufacturing in contrast to the ALD method. It should be noted, however, that the current limitations in terms of growth rate and throughput for lab scale ALD reactors are not fundamental [15]. With the use of batch processes but also with innovative developments, ALD may meet the throughput requirements of the solar cell industry, especially when ultrathin films are considered. Very recently it has for instance been shown that high deposition rates can be achieved with ALD by a reactor design separating the precursor and oxidation steps spatially instead of temporarily [16]. When the throughput requirements are met, the benefits of ALD can lead to its introduction in high volume manufacturing of solar cells.

In this contribution, we compare plasma ALD, thermal ALD and PECVD grown $\mathrm{Al}_{2} \mathrm{O}_{3}$ films in terms of surface passivation and material properties. We will also briefly address the underlying passivation mechanism in terms of chemical passivation (i.e. reduction of interface defect density) and field-effect passivation [17]. The message that we want to convey here is that good surface passivation can be obtained for a large range of $\mathrm{Al}_{2} \mathrm{O}_{3}$ material properties, which alleviates the requirements on the deposition methods, operating conditions and the reactor tools.

\section{EXPERIMENTAL}

A direct comparison between thermal ALD and plasma ALD was enabled by employing both methods in an 
Oxford Instruments OpALTM ALD reactor (operating pressure $\sim 170$ mTorr). For both ALD methods, trimethylaluminum $\left.\left[\mathrm{Al}\left(\mathrm{CH}_{3}\right)_{3}\right)\right]$ was used as the $\mathrm{Al}$ precursor in the first half cycle of the ALD process. During the second half cycle, either $\mathrm{H}_{2} \mathrm{O}$ or an $\mathrm{O}_{2}$ plasma was used for thermal and plasma ALD, respectively [5]. The films were deposited using substrate temperatures ranging from $50^{\circ} \mathrm{C}-400^{\circ} \mathrm{C}$ [14]. Cycle and purge times were optimized to reach a truly self-limiting ALD process at every $T_{\text {dep }}$. A schematic of the ALD cycles of the two methods are shown in Fig. 1. The PECVD process employed a continuous remote $\mathrm{O}_{2} / \mathrm{Ar}$ plasma and $\mathrm{Al}\left(\mathrm{CH}_{3}\right)_{3}$ as the $\mathrm{Al}$ precursor. Unlike ALD, the deposition rate for PECVD scales with the $\mathrm{Al}\left(\mathrm{CH}_{3}\right)_{3}$ flow introduced into the reactor. Rutherford backscattering spectroscopy and elastic recoil detection were used to determine the material properties in terms of atomic composition and mass density. Lifetime spectroscopy (Sinton WCT100) was used to evaluate the passivation performance. Annealing was done in $\mathrm{N}_{2}$, at $400^{\circ} \mathrm{C}$, for 10 minutes. The upper limit of the surface recombination velocity, $S_{\text {eff,max, }}$ was determined (at an injection level of $1 \times 10^{15} \mathrm{~cm}^{-3}$ ) by assuming that all recombination takes place at the surfaces.
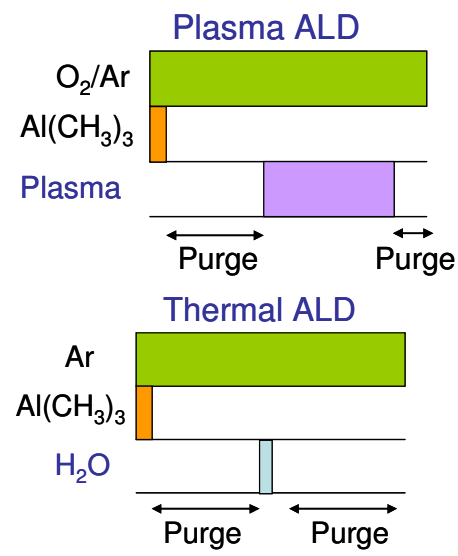

Figure 1. Schematic representation of the plasma ALD and thermal ALD cycle. During 1 cycle, typically $\sim 0.1 \mathrm{~nm} \mathrm{Al}_{2} \mathrm{O}_{3}$ is deposited. By repeating the cycles, the targeted film thickness can be reached with submonolayer growth control.

\section{RESULTS}

The maximum surface recombination velocity is plotted as a function of the deposition temperature for plasma and thermal ALD in Figure 2 and for PECVD in Figure 3. Significant differences were observed for as-deposited films. For plasma ALD and PECVD, the as-deposited surface passivation performance was very poor for $T_{\text {dep }}=$ $50-200^{\circ} \mathrm{C}$. For higher $T_{\text {dep }}$, the $S_{\text {eff }}$ values are observed to decrease significantly, which can be explained by an insitu anneal effect. For thermal ALD $\mathrm{Al}_{2} \mathrm{O}_{3}$, the asdeposited passivation performance was significantly better. After annealing, thermal ALD and plasma ALD afford a similar high level of surface passivation for $T_{\text {dep }}=$ $150-250^{\circ} \mathrm{C}$. $S_{\text {eff,max }}$ values as low as $3 \mathrm{~cm} / \mathrm{s}$ were obtained on $2 \Omega \mathrm{cm}$ p-type FZ c-Si.

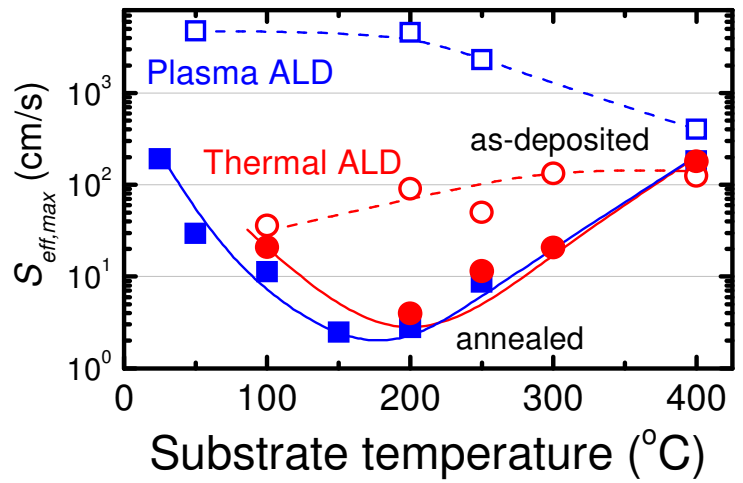

Figure 2. Influence of the deposition temperature on the passivation performance of as-deposited (open symbols) and annealed (closed symbols) $\mathrm{Al}_{2} \mathrm{O}_{3}$ films synthesized with plasma ALD (squares) and thermal ALD (circles). As substrates, $2 \Omega \mathrm{cm} p$-type FZ c-Si wafers were used.

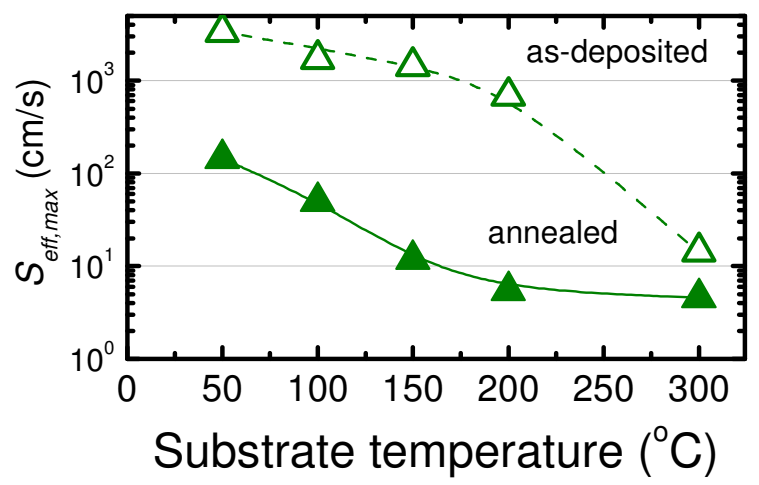

Figure 3. Influence of the deposition temperature on the passivation performance of as-deposited and annealed $\mathrm{Al}_{2} \mathrm{O}_{3}$ films synthesized with PECVD. As substrates, $2 \Omega$ cm p-type FZ $c$-Si wafers were used.

Also PECVD results in a comparable high level of surface passivation for $T_{d e p}=150-300^{\circ} \mathrm{C}$. Figure 4 shows the injection level dependent effective lifetime for two PECVD $\mathrm{Al}_{2} \mathrm{O}_{3}$ films, both deposited at $T_{\text {dep }}=200^{\circ} \mathrm{C}$, using a deposition rate of $\sim 5$ and $\sim 18 \mathrm{~nm} / \mathrm{min}$. An exceptional high effective lifetime of $\sim 20 \mathrm{~ms}$ is measured (at injection level of $5 \times 10^{14} \mathrm{~cm}^{-3}$ ), for the film deposited at $5 \mathrm{~nm} / \mathrm{min}$ on 3.5 $\Omega \mathrm{cm} n$-type $c$-Si. This corresponds to $S_{\text {eff }}<1 \mathrm{~cm} / \mathrm{s}$, amongst the lowest reported for $c$-Si. With this high level of surface passivation the effective lifetime of the minority carriers is mainly determined by Auger recombination in the Si bulk. The decreasing lifetime at low injection levels for these $n$-type wafers can be attributed to the formation of an inversion layer. This indicates the presence of a significant density of fixed negative charge $\left(Q_{f}\right)$ at the interface, which was confirmed by corona charging experiments that indicated a $Q_{f}$ value $>6 \times 10^{12} \mathrm{~cm}^{-2}[14]$. For higher deposition rates, $R_{d e p}=\sim 18 \mathrm{~nm} / \mathrm{min}$, the level of surface passivation is still very good with $S_{\text {eff }}<9 \mathrm{~cm} / \mathrm{s}$. For comparison, under the present conditions the maximum deposition rate for ALD was $\sim 1.8 \mathrm{~nm} / \mathrm{min}$ at $T_{\text {dep }}$ $=200^{\circ} \mathrm{C}$. 
For industrial solar cells, it is important to evaluate the stability of the surface passivation upon a high temperature firing process. It was already demonstrated that the ALD films exhibited sufficient thermal stability at temperatures $>800^{\circ} \mathrm{C}$ [8]. Also the PECVD $\mathrm{Al}_{2} \mathrm{O}_{3}$ films were sufficiently stable. $S_{\text {eff }}$ values < $10 \mathrm{~cm} / \mathrm{s}$ were measured (for $n$-type wafers $3.5 \Omega \mathrm{cm}$ ) after a firing process in an industrial belt line furnace (no metal paste was applied). The depassivation of interface defects at elevated temperatures, likely plays a role in the observed decrease of the surface passivation performance.

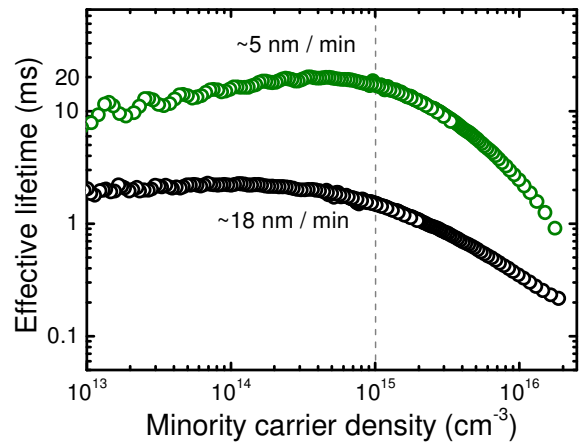

Figure 4. Effective lifetime for $\mathrm{Al}_{2} \mathrm{O}_{3}$ after annealing, deposited with PECVD at a deposition rate of $\sim 5$ and $\sim 18$ $\mathrm{nm} / \mathrm{min}$

Table 1 summarizes the material properties of the films deposited with the three methods, for the (optimal) substrate temperature of $200^{\circ} \mathrm{C}$. The main difference between plasma and thermal ALD $\mathrm{Al}_{2} \mathrm{O}_{3}$, is the higher hydrogen concentration for the latter (3.6 at.\%). As compared to the ALD films, the mass density of the PECVD $\mathrm{Al}_{2} \mathrm{O}_{3}$ film is significantly lower and the O/Al ratio of 1.61 indicates an excess of oxygen. Both observations are linked with the incorporation of significant amounts of hydrogen during the PECVD process. The deposition temperature has a significant impact on the structural properties of $\mathrm{Al}_{2} \mathrm{O}_{3}$, as discussed in detail in Ref. 14. Here we would like to emphasize that the passivation performance after annealing as displayed in Figs. 2 and 3, is rather insensitive to the significant differences in material properties between films deposited with the various deposition techniques and deposited within a broad range of substrate temperatures.

Table 1: Material properties of $\mathrm{Al}_{2} \mathrm{O}_{3}$ synthesized with PECVD, plasma ALD and thermal ALD at $T_{d e p}=200^{\circ} \mathrm{C}$.

\begin{tabular}{llll}
\hline Deposition process & {$[\mathrm{O}] /[\mathrm{Al}]$} & $\begin{array}{l}{[\mathrm{H}]} \\
\text { at.\% }\end{array}$ & $\begin{array}{l}\rho_{\text {mass }} \\
\left(\mathrm{g} / \mathrm{cm}^{3}\right)\end{array}$ \\
\hline PECVD (5 nm/min) & 1.61 & 7.5 & 2.7 \\
Plasma ALD & 1.52 & 2.7 & 3.1 \\
Thermal ALD & 1.52 & 3.6 & 3.0
\end{tabular}

Capacitance-voltage and second harmonic generation experiments were used to study the chemical and fieldeffect passivation underlying the surface passivation properties [17]. Briefly, the lack of significant surface passivation for as-deposited $\mathrm{Al}_{2} \mathrm{O}_{3}$ deposited with plasma ALD (and PECVD) was attributed to a very high interface defect density, despite the presence of a significant negative $Q_{f}>10^{12} \mathrm{~cm}^{-2}$. We have demonstrated that the defective interface can be attributed to plasma induced damage during deposition [17]. After annealing, both plasma and thermal ALD $\mathrm{Al}_{2} \mathrm{O}_{3}$ exhibited a low interface defect density with $D_{\text {it }}$ values of $\sim 10^{11} \mathrm{eV}^{-1} \mathrm{~cm}^{-1}$ or below. $Q_{f}$ values were higher for plasma ALD and PECVD $\left(Q_{f}>\right.$ $\left.5 \times 10^{12} \mathrm{~cm}^{-2}\right)$ than for thermal ALD $\left(Q_{f} \sim 2 \times 10^{12} \mathrm{~cm}^{-2}\right)$. Chemical passivation therefore plays a more prominent role for the thermal ALD $\mathrm{Al}_{2} \mathrm{O}_{3}$ films. Taken together, the results show that the chief effect of annealing was the improvement of the chemical passivation for plasma ALD $\mathrm{Al}_{2} \mathrm{O}_{3}$ films, whereas for thermal ALD, the increase of the field effect passivation was more pronounced [17].

\section{CONCLUSION}

$\mathrm{Al}_{2} \mathrm{O}_{3}$ films deposited with plasma ALD, thermal ALD and PECVD afforded a high level of Si surface passivation, for a relatively broad range of substrate temperatures during deposition. Similar to ALD, the PECVD $\mathrm{Al}_{2} \mathrm{O}_{3}$ films exhibited a high fixed negative charge density after annealing and a good firing stability. The results demonstrate that the passivation performance is relatively insensitive to the structural properties of bulk $\mathrm{Al}_{2} \mathrm{O}_{3}$, which makes $\mathrm{Al}_{2} \mathrm{O}_{3}$ a robust solution for silicon surface passivation in photovoltaics.

\section{ACKNOWLEDGMENTS}

This work is supported by the German Ministry for the Environment, Nature Conservation and Nuclear Safety (BMU) under contract number 0325150 ("ALADIN").

\section{REFERENCES}

[1] B. Hoex, J. Schmidt, R. Bock, P. P. Altermatt, M. C. M van de Sanden, W. M. M. Kessels, Appl. Phys. Lett. 91,112107 (2007).

[2] G. Agostinelli, A. Delabie, P. Vitanov, Z. Alexieva, H. F. W. Dekkers, S. De Wolf, G. Beaucarne, Sol. Energy Mater. Sol. Cells 90, 3438 (2006).

[3] B. Hoex, J. Schmidt, P. Pohl, M. C. M. van de Sanden, W. M. M. Kessels, J. Appl. Phys 104, 044903 (2008).

[4] J. Benick, A. Richter, M. Hermle, S. W. Glunz, Phys. Status Solidi RRL 3, 233 (2009).

[5] G. Dingemans, R. Seguin, P. Engelhart, M. C. M. van de Sanden, W. M. M. Kessels, Phys. Status Solidi RRL 4, 10 (2010).

[6] J. Benick, B. Hoex, M. C. M. van de Sanden, W. M. M. Kessels, O. Schultz, S. W. Glunz, Appl. Phys. Lett. 92, 253504 (2008). 
[7] J. Schmidt, A. Merkle, R. Brendel, B. Hoex, M. C. M. van de Sanden, W. M. M. Kessels, Prog. Photovoltaics 16, 461 (2008).

[8] G. Dingemans et al., in: Proceedings of the 34th IEEE Photovoltaics Specialists Conference, Philadelphia, USA (2009).

[9] J. Schmidt et al., in: Proceedings of the 23rd European Photovoltaic Solar Energy Conference, Valencia, Spain (2008).

[10] G. Dingemans, R. Seguin, P. Engelhart, F. Einsele, B. Hoex, M.C.M. van de Sanden, W. M. M. Kessels, J. Appl. Phys 106, 114907 (2009).

[11] S. Miyajima, et al., in: Proceedings of the 23rd European Photovoltaic Solar Energy Conference, Valencia, Spain (2008).

[12] T.-T. Li and A. Cuevas, Phys. Status Solidi RRL 3, 160 (2009).
[13] P. Saint-Cast, D. Kania, M. Hofmann, J. Benick, J. Rentsch, R. Preu, Appl. Phys. Lett. 95, 151502 (2009).

[14] G. Dingemans, M. C. M. van de Sanden, W. M. M. Kessels, Electrochem. Solid- State Lett. 13, H76 (2009).

[15] W.M.M. Kessels et al., in: Proceedings of the 33rd IEEE Photovoltaics Specialists Conference, San Diego, U.S.A. (2008).

[16] See: www.levitech.nl and www.tno.nl.

[17] G. Dingemans et al., submitted for publication (2010). 